\title{
Personal Nationalism in a Marital Relationship: Emotive and Gendering Construction of National Experience in Romantic Correspondence
}

\author{
Reetta Eiranen
}

\section{INTRODUCTION}

Recent study of nationalism has increasingly paid attention to personal meanings and people's active agency in the interpretation and production of the nation; for instance, through concepts like banal nationalism and everyday nationalism. ${ }^{1}$ In addition to these approaches, which often concentrate on "from below" viewpoint and on everyday practices, the concept of personal nationalism or a "personal approach" can offer a

\footnotetext{
${ }^{1}$ Michael Skey \& Marco Antonsich, eds, Everyday Nationhood: Theorising Culture, Identity and Belonging After Banal Nationalism (London: Palgrave Macmillan, 2017); Andreas Stynen, Maarten Van Ginderachter \& Xosé M. Núñez Seixas, eds, Emotions and Everyday Nationalism in Modern European History (London: Routledge, 2020).
}

R. Eiranen $(\square)$

Tampere University, Tampere, Finland

(C) The Author(s) 2021

V. Kivimäki et al. (eds.), Lived Nation as the History of Experiences and Emotions in Finland, 1800-2000, Palgrave Studies in the History of Experience, https://doi.org/10.1007/978-3-030-69882-9_4 
fruitful and complementary starting point for the analysis of national thought and commitment. ${ }^{2}$

The connection between the personal and public spheres has been vital to the emotional power of nationalism. The ideology has gained strength from a link to other elements of individual and group identities, especially those conceived of as "natural," such as gender and family. Family formed a mediating structure between the public and the private, and the ideals concerning it were central to nationalist thought in Europe in the nineteenth century. Personal and private matters, activities and attachments gained wider significance by being linked with the nation. ${ }^{3}$ The viewpoint of personal nationalism offers the possibility of looking at how often abstract national ideals were interpreted and constructed in concrete lived and experienced relationships, and what they meant to the experiencing subjects.

This chapter focuses on a couple, Natalia and M. A. Castrén, who belonged to the central networks of emerging Finnish nationalist thought and were deeply committed to the cause. The object of analysis is their romantic correspondence, written in 1850 during their engagement. ${ }^{4}$ M. A. Castrén was a prominent academic, and, in a broader context, the couple was part of the European educated classes and protagonists of national movements in the mid-nineteenth century. ${ }^{5}$ It is of special interest to look at the personal experiences that fueled these key agents'

${ }^{2}$ Anthony P. Cohen, "Personal Nationalism: A Scottish View of Some Rites, Rights, and Wrongs," American Ethnologist 23:4 (1996), 802-15; Raúl Moreno-Almendral, "Reconstructing the history of nationalist cognition and everyday nationhood from personal accounts," Nations and Nationalism 24:3 (2018), 648-68.

${ }^{3}$ Lloyd Kramer, Nationalism in Europe \& America: Politics, Cultures, and Identities since 1775 (Chapel Hill: University of North Carolina Press, 2011), 14, 102-15. See also George Mosse, Nationalism and Sexuality: Middle-Class Morality and Sexual Norms in Modern Europe (Wisconsin: University of Wisconsin Press, 1988 [1985]).

${ }^{4}$ The chapter is based on a subchapter of my PhD dissertation, Reetta Eiranen, Lähisubteet ja nationalismi: Aate, tunteet ja sukupuoli Tengströmin perbeessä 1800-luvun puolivälissä (Tampere: Tampere University, 2019a). (The title in English: Close Relationships and Nationalism: The Cause, Emotions and Gender in the Tengström Family in Mid-Nineteenth Century Finland). The correspondences were originally written in Swedish. All the translations into English are the author's.

${ }^{5}$ The term "protagonist" ( Vorkämpfer) derives from Miroslav Hroch's comparative work on national movements. There have recently been initiatives aimed at studying this central but diverse group more closely. See Joep Leerssen, Xosé-Manoel Seixas \& Kasper Swerts, "Relaunching Studies on National Movements," Studies on National Movements 4 (2019), 2-3. 
commitment to the nationalist cause. Actually, it is quite phenomenal that in the nineteenth century so many people took up nationalism as their idealistic life goal. In a way, a simple question remains: Why did they do it? Personal nationalism can offer answers by pointing toward the ways in which the ideology affected and was entangled with people's selves, lives, and closest relationships. Personal nationalism shows how the interpretations of the ideology are linked to personal backgrounds, traits, and experiences. It opens up the opportunity to analyze how the personal meanings connected with the cause were transformed into building blocks of the self and one's own life, and, vice versa, how these subjective meanings motivated commitment to the cause. In the Castréns' case, this chapter asks how nationalism intertwined with the construction of their selves and their marital relationship. In this, the emotive and gendered construction of national experience occupied a central position.

An in-depth analysis of personal lived experiences requires looking at them in actual, individual lives. The focus on individuals as well as on their marital relationship also makes it possible to overcome persistent and often gendered dichotomies such as the emotional-rational and the public-private. It opens up deconstructing viewpoints on the national canons as well. ${ }^{6}$ Nevertheless, the "personal" and the "biographical" are not to be seen as alternative but as complementary approaches. The biographical knowledge of the research subject forms the prerequisite as well as the context for experiential analysis of personal narratives. The national can frame the ways experiences are constructed, but "biographical" experiences also shape the way in which the national is interpreted. ${ }^{7}$

Furthermore, the concepts of experience and narration need to be scrutinized and not taken for granted within the personal / biographical framework. In this chapter, the letters dealt with are approached as experiential self-narrations. Drawing on the existential-hermeneutical tradition, the structures of experience and interpretation are seen as analogous-understanding something-as-something (Etwas als Etwas). Narration is defined as interpretation that pertains to experiences that are

\footnotetext{
${ }^{6}$ Annika Berg \& al, "Couples in Science and Politics: Intellectual Partnerships in Sweden, c. 1900-c. 1950," in Par $i$ vetenskap och politik. Intellektuella äktenskap $i$ moderniteten, ed. by Annika Berg, Christina Florin \& Per Wisselgren (Umeå: Boréa, 2011), 365-70; Irma Sulkunen, "Biography, Gender and the Deconstruction of a National Canon," Gendering Historiography: Beyond National Canons, ed. by Angelika Epple \& Angelika Schaser (Frankfurt: Campus), 65-77.

${ }^{7}$ Cf. Moreno-Almendral (2018), 656-7.
} 
already interpretations in themselves ("a double hermeneutics"). In selfnarration, the present I gives sense and meaning to past experiences and future expectations. The narrating I chooses the elements of her or his narrative and puts these elements in relation to each other; in this manner endowing them with meaning. A vital premise is that interpretations construct the reality instead of merely reflecting it. ${ }^{8}$ Here, the writing of letters is seen as part of this interpretative, experiential construction of the self and the world. Combining self-narration and personal nationalism means analyzing how the narrating I incorporates nationalism in her or his self-narration, that is, to the construction of oneself and one's experiences.

In this chapter, emotions and gender are seen as central ways of giving meaning to one's national experience. The analysis draws on cultural anthropologist William Reddy's concept of emotive, by which he refers to emotional expressions that evoke and construct emotions, and thus shape the emotional experience. ${ }^{9}$ Gender can be understood in an analogous way. Gender is performatively produced by linguistic and bodily repetitions of gestures and ways of expression where the performative process has ontological consequences. ${ }^{10}$ To summarize, emotive and gendered experiences, as with any experiences, are constructed in the ongoing process of interpretation, linguistically as well as bodily. I argue that emotive and gendering narrations, which consist of larger narrative wholes instead of individual words or concepts, construct and produce emotional and gendered experiences.

This chapter will tackle personal nationalism and its emotive and gendered construction in the experiential narrations of letter-writing. The first section discusses the construction of the Castréns' emotional relationship in relation to the gender ideals of the time and to the particular ways the couple connected those ideals to the nationalistic cause. The second section focuses on the couple's gendered emotional dynamics, the premise of which

${ }^{8}$ See, e.g., Hanna Meretoja, "On the Use and Abuse of Narrative for Life: Towards an Ethics of Storytelling," in Life and Narrative: The Risks and Responsibilities of Storying Experience, ed. by Brian Schiff, A. Elizabeth McKim \& Sylvie Patron (Oxford: Oxford University Press, 2017), 81-3; Andreea Deciu Ritivoi, "Identity and Narrative," in Routledge Encyclopedia of Narrative Theory, ed. by David Herman, Manfred Jahn and Marie-Laure Ryan (New York: Routledge, 2005), 231-5; Paul Ricœur, "Life in Quest of Narrative," in On Paul Ricour: Narrative and Interpretation, ed. by David Wood (London: Routledge, 1992), 21-3.

${ }^{9}$ William M. Reddy, The Navigation of Feeling: A Framework for the History of Emotions (Cambridge: Cambridge University Press, 2001), 103-5.

${ }^{10}$ Judith Butler, Bodies that Matter: On the Discursive Limits of "Sex" (London: Routledge, 1993). 
was the "genius" man who had suffered for his country. Contradictory to general stereotypes, the case brings together masculine passion and inner feeling as a driving force in national achievements as well as the strong emotional control required of the woman. Lastly, the chapter will concentrate on national science as a joint project field of the spouses, something that concretized the need to express readiness for self-sacrifice, an element central to nationalist ideologies. The man's scholarly work was central to both spouses' personal nationalism but in different gendered and emotional ways.

\section{The “National Couple” Complementing Each Other}

M. A. Castrén (1813-52) and Natalia Tengström (1830-81, Castrén after their marriage) had backgrounds that made them a "perfect" national match.

M. A. Castrén came from a clerical family from Northern Finland's mostly Finnish-speaking area, but he was Swedish-speaking. He started his studies at the Imperial Alexander University in Helsinki in 1830 and was inspired by the rising wave of Finnish cultural nationalism. The publication of the Finnish national epic Kalevala in 1835 was instrumental in directing his interest toward his research fields, the Fenno-Ugric languages and folklore. Castrén belonged to the social network of the most prominent advocates of the Finnish cause at the time. He socialized, for instance, with "the national poet" J. L. Runeberg, "the national philosopher" J. V. Snellman, and the compiler of Kalevala, Elias Lönnrot. ${ }^{11}$ From his first field expeditions, he acquired "an urge to wander." Later on, he was driven by a sense of duty - "a deep need to fill my measure," as he wrote in his diary. ${ }^{12}$ In the 1840s, he travelled extensively, more than 50,000 kilometers, in Siberia studying the Fenno-Ugric languages and peoples. The conditions in the expeditions were harsh. He travelled in the cold climate over long distances and rough terrains among few and remote people. After a couple of years, he started suffering from pulmonary tuberculosis, and by the time he returned to Finland for good in 1849 he was also suffering from dysentery

\footnotetext{
${ }^{11}$ Tapani Salminen, "Castrén, Matthias Alexander (1813-1852)," in Kansallisbiografia (National Biography of Finland), https://kansallisbiografia.fi/kansallisbiografia/henkilo/3164, accessed 17 August 2020. Kaisa Häkkinen, "Matthias Alexander Castrén suomen kielen tutkijana," in Per Urales ad Orientem: Iter polyphonicum multilingue (Helsinki: Suomalais-Ugrilaisen Seuran Toimituksia 264), 103-14.

${ }^{12}$ Kaisa Häkkinen, "Suomen kielitieteen nousu 1700- ja 1800-lukujen vaihteessa," in Herder, Suomi ja Eurooppa, ed. by Sakari Ollitervo \& Kari Immonen (Helsinki: SKS, 2006), 309-10, 486.
} 
and scurvy. The expeditions made him an early international pioneer in linguistic fieldwork and ethnolinguistics. ${ }^{13} \mathrm{M}$. A. Castrén's aim was to show that the Finnish people were not detached from the world and world history but were related to at least a sixth of mankind. ${ }^{14}$

The prestigious and academic Swedish-speaking Tengström family was also central to the nationalistic networks of the time. The tradition of supporting and sympathizing with Finnishness dated back to Natalia Tengström's grandfather, the important political figure Bishop Jacob Tengström, who emphasized the need to develop and strengthen Finnishness-separate from Swedishness-after Sweden ceded the area to Russia in 1809. Natalia Tengström's father, Professor of Philosophy J. J. Tengström, was an important background figure in the rise of the Finnish national movement through his writing and teaching. In this family surrounding, Natalia Tengström and her siblings also developed national interest. Her brother was an enthusiastic advocate of the Finnish cause in student circles, whereas Natalia Tengström and her two sisters founded their own study group dedicated to the Finnish language. She also read rather widely, both by herself and with her sisters in their book club. Siblinghood enabled and promoted the national activities, since these could be taken up and planned together. ${ }^{15}$ After M. A. Castrén returned from his last expedition to Siberia as a famous linguist and explorer, he and Natalia Tengström, who had grown into a young woman by then, found each other in the common social circle. They got engaged in January 1850 and married in October of the same year (Figs. 4.1 and 4.2).

The emerging nationalist ideology was closely connected with the construction of gender and emotional ideals. In the nineteenth century, the gender difference and complementarity of sexes, and hence gendered separate spheres, were emphasized. The stark division of the complementarity model was based on rising biological and philosophical ideas. Instead of considering the woman as a weaker version of the man, the sexes were seen as different in their essence. The polarized ideals saw

\footnotetext{
${ }^{13}$ Salminen (2002); Fred Karlsson, "Castrén, Matthias Alexander (1813-1852)," in Encyclopedia of Language \& Linguistics, 2nd ed., ed. by Keith Brown (Amsterdam: Elsevier, 2006), 234.

${ }^{14}$ M. A. Castrén to J. V. Snellman 18 October 1844, in J. V. Snellman, Samlade arbeten IV (Helsingfors: Stadrådets kansli, 1994), 621.

${ }^{15}$ Reetta Eiranen, "Emotional and Social Ties in the Construction of Nationalism: A Group Biographical Approach to the Tengström Family in Nineteenth-Century Finland," Studies on National Movements 4 (2019b), 6-7, 16-21.
} 
Fig. 4.1 M. A. Castrén. (Photo: Charles Riis, The Society of Swedish Literature in Finland, SLSA 1185)

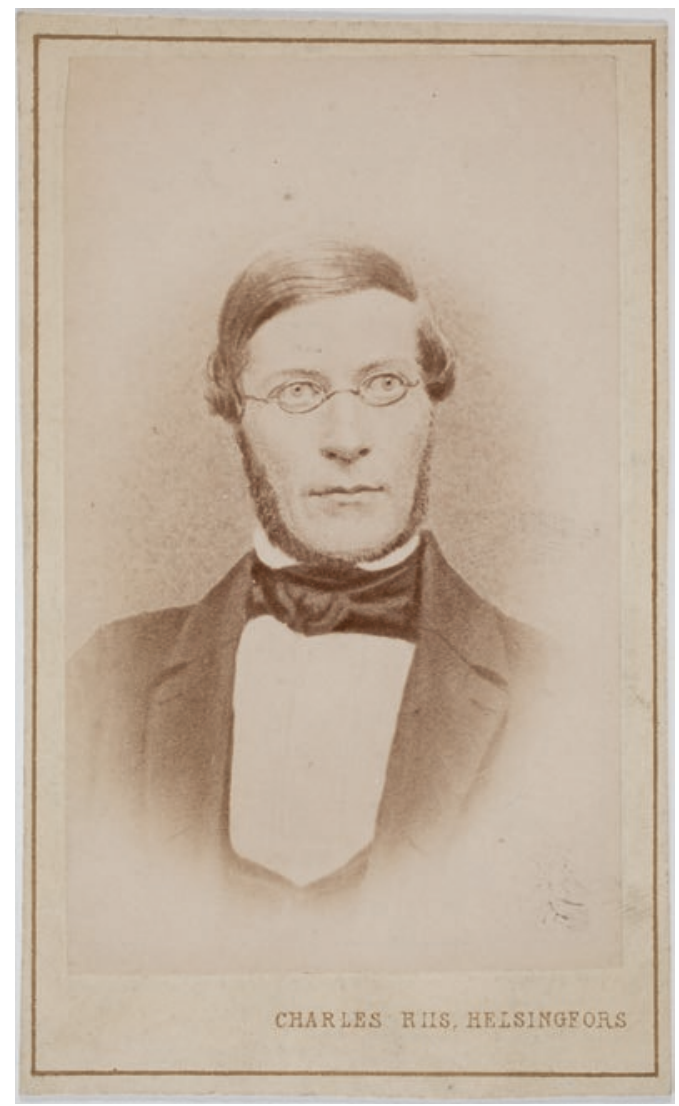

their fulfillment in the heterosexual love relationship where a complete whole was formed. Also, the ideal of the nuclear family was on the rise. In nationalist thought, the nation was equated with the family, which evoked "timeless" emotional meanings. These bourgeois ideals were reflected in the gender order of the nation, since the educated middle class aspired to make their values those of the nation and strove toward achieving a leading position in society. ${ }^{16}$ The man and the woman were

\footnotetext{
${ }^{16}$ See, e.g., Kai Häggman, "The Century of Family: The Ideal Family and Bourgeois Lifestyle in Nineteenth-Century Finland," in Kai Häggman, Perheen vuosisata (Helsinki: Suomen Historiallinen Seura, 1994), 247-52; Stephanie A. Shields, "Passionate Men, Emotional Women: Psychology Constructs Gender Difference in the Late Nineteenth Century," History of Psychology 10:2 (2007), 94, 96-7; Kramer (2011), 103-10.
} 
Fig. 4.2 Natalia

Castrén. (Photo:

C.A. Hårdh, The Society

of Swedish Literature in

Finland, SLSA 1185)

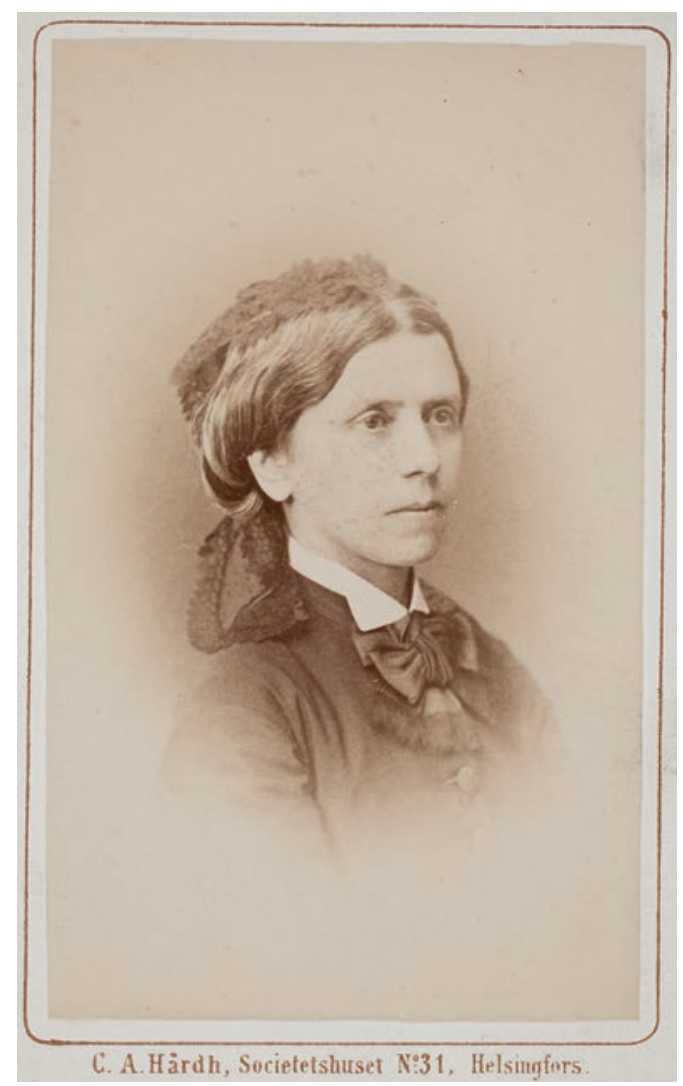

considered apparently equal but nevertheless different, which also led to their different roles within the context of the nation.

The complementarity model has usually been interpreted as representing the woman as emotional and the man as rational. However, scholar of gender and psychology Stephanie A. Shields has argued that the idea was rather that rationality and emotionality manifested themselves differently in the different genders. The man's rationality was abstract whereas the woman's was practical. The man's emotionality could be seen as a positive force whereas the woman's was considered unstable sentimentality. In general, the man's emotionality was valued, but irrational and uncontrolled outbursts could put masculinity into question. In the end, the man 
was to control his emotions with his reason. ${ }^{17}$ Emotionality also contained a class aspect: emotional sensibility and reflection on one's emotions were seen as traits of the educated classes whereas the lower classes' ability to feel was not seen to be equally refined. ${ }^{18}$

In M. A. Castrén's epistolary narration, the ideal selves—or "essences"were strongly interdependent. He declared that in Natalia Tengström, he loved "the glad temperament, the warm heart, the high feeling for truth, for knowledge, for the fatherland, for everything noble and good." For his part, he assumed that she loved in him "the spirit that has shown itself to be ready, according to its measure, to be roused for everything true and noble." 19 With regard to other Finnish nineteenth-century male nationalists, it has been shown that feelings for the fatherland and for the spouse intertwined..$^{20}$ In the Castréns' case, it was not so much about identifying the loved one with the nation but about loving the nation together. In M. A. Castrén's interpretation, both spouses fulfilled the gendered ideals, but an important addition was their deep commitment to the national cause, something that elevated them and their relationship even further and made their feelings even deeper. The national cause was deeply interwoven with their past, and with the interpretation of themselves as the reason for their mutual feelings. It had profound personal meanings. In this relationality, by narrating the woman in an idealistic manner, the man was actually proving that by being her choice and partner, he too fulfilled the ideal. ${ }^{21}$

${ }^{17}$ Shields (2007), 92, 97-8; Ute Frevert, Emotions in History: Lost and Found (Budapest: CEU Press, 2011), 116-17; Eva-Helen Ulvros, Kvinnors Röster: Livsöden från det moderna Sveriges framväxt (Lund: Historiska Media, 2016), 95-7.

${ }^{18}$ Juha Siltala, Valkoisen äidin pojat: Siveellisyys ja sen varjot kansallisessa projektissa (Helsinki: Otava, 1999), 15, 32-3; Marc Brodie \& Barbara Caine, "Class, Sex, and Friendship: the Long Nineteenth Century," in Friendship: A History, ed. by Barbara Caine (London: Routledge, 2014), 238-40; Ulvros (2016), 95-7.

${ }^{19}$ The Society of Swedish Literature in Finland (SLS), Gunnar Castréns släktarkiv (GCSA), Folder 7, M. A. Castrén (MAC) to Natalia Castrén (NC), 2 July 1850. Before October 1850 Natalia's last name was still Tengström, but the letters are archived under her married name of Castrén.

${ }^{20}$ E.g., Siltala (1999), 67-71; Marja Jalava, Minä ja maailmanhenki: Moderni subjekti kristillis-ideologisessa kansallisajattelussa ja Rolf Lagerborgin kulttuuriradikalismissa n. 18001914 (Helsinki: SKS, 2005), 177-8.

${ }^{21}$ See also Reetta Eiranen, "The Narrative Self: Letters and Experience in Historical Research," in Private and Public Voices: An Interdisciplinary Approach to Letters and Letter Writing, ed. by Karin Koehler \& Kathryn McDonald-Miranda (Oxford: Inter-Disciplinary Press, 2015), 88-9. 
The young Natalia Tengström comes forth in her letters as lively and witty, even somewhat ironic, qualities which crystallized in her nickname Little Nattu, which referred to her young age and was a somewhat childlike shorthand for Natalia. ${ }^{22}$ Nevertheless, according to the future Ms. Castrén, the upcoming marriage had a sobering effect on her. For her, the fact that the perfect man had chosen her was not a guarantee of her own worth. The man's idealistic expectations worried her, and she did not want him to have too good a picture of her. She claimed that he did not know how inept she was and worried about how she could be as good as she should and wanted to be. She appealed to God to aid her in living up to expectations. Paradoxically, by narrating herself in this modest and gendered way, she actually confirmed the fact that she fulfilled the ideal. ${ }^{23}$

Hermeneutically, the self is constantly reinterpreted in relation to the narratives the culture proposes to us and to the ways in which people use these narratives in shaping their experiences. Reciprocally, these cultural narratives are reinterpreted in actual, lived situations. ${ }^{24}$ In the relationality of selves, the writers had the possibility of narrating themselves but also of becoming narrated by the other. ${ }^{25}$ In letter writing, the writers can "propose" stories of and to each other and, in this way, define or try to define the other as well as their mutual relation. The complementarity model can be read as a cultural narrative that M. A. Castrén and Natalia Tengström appropriated to their own lived situation. However, it is important to note that it was not (as it never is) just about repeating a readymade script. Instead, the couple, and especially the man, made strong interpretations of the cultural narratives available to them, and in these interpretations, nationalism represented an important element. Also, M. A. Castrén strongly proposed a specific story to his fiancée concerning himself, her, and their relationship. The woman was left with the role of complying, and, as said, in this way she actually played along with the script.

In the self-narrations drawing from their past, national ideals were woven into their selves and into the emergence of their relationship, but

${ }^{22}$ See, e.g., The National Library of Finland (NLF), Kellgreniana, Coll. 99.3, NC to Sofi Kellgren, 3 March [1850], 5 September 1850; SLS, GCSA, Folder 7, Josephine Pipping to Natalia Castrén, tredje dag jul [1850].

${ }^{23}$ SLS, GCSA, Folder 1, NC to MAC, 24 February 1850, 1 March 1850, 17 September 1850. See also Eiranen (2015), 88-9.

${ }^{24}$ Ricœur (1992), 21, 32-3; Meretoja (2017), 82-3.

${ }^{25}$ Adriana Cavarero, Relating Narratives: Storytelling and Selfhood, trans. by Paul A. Kottman (London: Routledge, 2006 [1997]). 
these ideals also had a bearing on their future expectations. The Castréns' letters constructed the idea of a predestined union, where the ideal inner essences of each spouse drove them to each other. In line with the contemporary ideal of love marriage, M. A. Castrén thought that their pure feelings, but also the knowledge of each other's noble principles, which in this case were connected to the national cause, would secure their mutual love and happiness. A perception of divine guidance was intertwined with this: he was sure that God, not chance, had made them for each other and sealed their union. ${ }^{26}$ In her answer, Natalia Tengström stated that she had praised the Lord who had created such a beautiful life and given her "you to love and live for." 27 In the man's letters, providence had brought the ideal complementary essences together. The woman did not bring up her own superiority but, again, thanked God more passively for the man and the happiness she had been granted.

The pair's social circle reinforced the idea of a complementary and nearly perfect national couple. The older esteemed friends J. L. Runeberg (who also was Natalia Tengström's uncle) and J. V. Snellman praised Natalia Tengström, which convinced M. A. Castrén even more about their compatibility. Natalia Tengström, for her part, felt even more pressure to live up to the ideals. ${ }^{28}$ Also Fredrika Runeberg, Natalia Tengström's aunt and J. L. Runeberg's wife, had a very positive attitude toward the match, to which she attached ideological meanings. She was glad that Natalia Tengström's "happy eyes and kind warm heart" would bring comfort and warmth to the life of the man who had "sacrificed so many years of coldness and discomfort for his Own Country." 29 In the relatives' assessments, the viewpoint of social prestige was also present, though vaguely downplayed. J. L. Runeberg had joked that his wife would get another portrait of a famous relative for her drawing room. For Fredrika Runeberg, M. A. Castrén was "an honorary son-in-law" but she expressed the conviction that Natalia Tengström was in love with the man and that it was not

\footnotetext{
${ }^{26}$ SLS, GCSA, Folder 7, MAC to NC, 2 July 1850, s.a. [16 September 1850?], s.a. [23 September 1850].

${ }^{27}$ SLS, GCSA, Folder 1, NC to MAC, 26 September 1850.

${ }^{28}$ SLS, GCSA, Folder 7, MAC to NC, 17-19 February 1850, 2 July 1850; SLS, GCSA, Folder 1, NC to MAC, 24 February 1850. See also Eiranen (2015), 88-9.

${ }^{29}$ SLS, Handskrifter av. J.L. Runeberg och Fredrika Runeberg, SLS-Samlingen, SLSA 1106, Fredrika Runeberg to Carolina Tengström, Fredag [January 1850]. Italics originally in Finnish, "Oma Maa."
} 
a question of calculation. ${ }^{30}$ Nevertheless, even mentioning this reveals that it was a possibility.

The key marriage ideal of the time was freely chosen, romantic love. ${ }^{31}$ In their correspondence, the couple reassured each other of their feelings, which was, of course, typical of romantic letter-writing. ${ }^{32}$ In fact, as with many contemporary brides, Natalia Tengström had mixed feelings as the wedding day approached. However, she emphasized with similar wording to both her fiancé and sister that the union was her "own free choice" and that she was as fond of her fiancé as much as she could be of anyone. ${ }^{33}$ In addition, it was now her turn to appeal to Uncle Runeberg's authority. She shared her feelings through citing the following lines from the poet: "More than life, I found, is to love." 34 The emotive repetition in the letters, in some cases even via similar phrases, constructed and strengthened the emotional experience and the mutual relationship. Even though the national commitment formed an integral part of their match, the couple needed to assure themselves, but also their social circle, of their sincere emotional motives.

\section{Emotionally Dependent Genius}

In the ethos of the nineteenth-century educated middle class, the crucial task of the woman was to support her husband, and to prepare the home to be a safe haven for the husband who was bearing the strain of struggles in the outside world. In the nationalistic context, this meant that the man sacrificed himself for the nation in the public arena while the woman could do her part for the nation by sacrificing herself for him in the private sphere of the home. ${ }^{35}$

${ }^{30}$ SLS, Handskrifter av. J.L. Runeberg och Fredrika Runeberg, SLS-Samlingen, SLSA 1106, Fredrika Runeberg to Carolina Tengström, Fredag [January 1850].

${ }^{31}$ See, e.g., Ulvros (2016), 21-2.

${ }^{32}$ E.g., SLS, GCSA, Folder 7, MAC to NC, 28 June 1850, 2 July 1850; SLS, GCSA, Folder 1, NC to MAC, 30 June 1850, 2 July 1850.

${ }^{33}$ NLF, Kellgreniana, Coll. 99.3, NC to Sofi Kellgren, 5 September 1850; SLS, GCSA, Folder 1, NC to MAC, 17 September 1850.

${ }^{34}$ SLS, GCSA, Folder 1, NC to MAC, 26 September 1850.

${ }^{35}$ Mosse (1988), 18-19; Jalava (2005), 184, 190-2; John Tosh, A Man's Place: Masculinity and the Middle-Class Home in Victorian England (New Haven: Yale University Press, 2007 [1999]), 6, 54-6. 
M. A. Castrén was emotionally and even existentially dependent on his beloved. From the viewpoint of personal nationalism, it is striking that his scientific and national task intertwined tightly with the feelings toward and the relationship with his fiancée.

In his narration, M. A. Castrén tied his science, fatherland, and beloved together into an integrated trinity and an existential necessity. He expressed the belief that nothing else really mattered as long as he stayed true to "my science, my fatherland and You, good Natalia." ${ }^{36}$ On another occasion he named the same trinity as the only conditions necessary for his bliss, but in reverse order "Natalia, fatherland, science." Interestingly, he had started to write "science" as the second word on the list but crossed it out so as to put "fatherland" between the beloved and science, which indicates that it was important for him that it was in the middle. ${ }^{37}$ In a variation on the theme, Natalia Tengström's love was “as necessary as the air I breathe, it is a condition of my existence as a human being, as a scholar and as a citizen." 38

It appears that for M. A. Castrén, nationalism acted as a mediator between the abstract common good and personal happiness. This can be understood through the Hegelian ideas underlying the national movements of the time and their Finnish interpretation: the world spirit advanced through particular national spirits. ${ }^{39}$ In the Castréns' case, science represented the general world spirit and its advancement; hence, the advancement of the whole of human kind. But importantly, this was done through national science. In this continuum, the beloved represented the private and the family, which, for their part, formed the basis for the national. They supported the man as a human being and enabled him to work for the nation and science and through them for the common good.

The hardships he had endured during his nationally motivated expeditions to Siberia formed the background for M. A. Castrén's self-narration and the justification for his future expectations. This was an integral part of his personal nationalism within the romantic relationship. In general, his fiancée provided him with peace and recreation of mind and, through them, energy for his work. Crucially, M. A. Castrén felt that he needed the

\footnotetext{
${ }^{36}$ SLS, GCSA, Folder 7, MAC to NC, 3 March 1850.

${ }^{37}$ SLS, GCSA, Folder 7, MAC to NC, s.a. [26 September 1850?].

${ }^{38}$ SLS, GCSA, Folder 7, MAC to NC, s.a. [16 September 1850?].

${ }^{39}$ On Finnish interpretations of Hegelianism, see Marja Jalava, J. V. Snellman: Mies ja suurmies (Helsinki: Tammi, 2006), 40-5, 247.
} 
love and kindness of his beloved even more due to the difficult experiences he had undergone. He worried that those trials had made him reticent and had hardened his shell. During his travels, he had forsaken any hope of personal happiness. Finding love with Natalia Tengström was in strong contrast to the long lonely years. ${ }^{40}$ At the time, young men would often warn their fiancées of their unspecified weaknesses or flaws for which they needed the woman's understanding and support. ${ }^{41}$ In M. A. Castrén's narration, the reasons for his shortcomings were ennobled by the national motivations that had caused them.

As a matter of fact, M. A. Castrén considered Natalia Tengström's "warm heart" a reward, and compensation for his many troubles-from "a just providence." Curiously enough, he emphasized that he did not "flatter" his fiancée by saying so. ${ }^{42}$ This line of thought has the flavor of gendered demeaning, even though a benign interpretation could be that he felt that only through his endeavors had he become a man worthy of Natalia Tengström's love. Nevertheless, the aspect of the man "earning" the woman's love and understanding through great national deeds formed an important undertone in the "relational nationalism" of their relationship, and hence, of their personal nationalisms.

In his letters, M. A. Castrén elevated his intense inner emotional life. Despite his outward appearance, he had "by nature a restlessly stormy mind." He pondered that he might be too much of a slave of his emotion and wondered that it had not led to his ruination. But in actuality, he idealized his inner feeling as God's will and work: “ $[\ldots]$ it is this feeling I have to thank for all the little I will accomplish in this life." ${ }^{43} \mathrm{He}$ stated that he had always "just followed the impulses of my heart and let God look after the rest." ${ }^{44}$ In his view, it was thus inner feeling that had actually enabled his scientific and nationalistic achievements.

Masculine passion was actually an important part of nineteenth-century politics, and it was recognized that great and exceptional deeds were fueled by inner passion. This inner feeling enabled a man to commit deeply

${ }^{40}$ SLS, GCSA, Folder 7, MAC to NC, 17.-19 February 1850, 28 June 1850, s.a. [23 September 1850?]; NLF, Kellgreniana, Coll. 99.4, MAC to Robert Tengström 6/18 March 1846.

${ }^{41}$ Tosh (2007), 56.

${ }^{42}$ SLS, GCSA, Folder 7, MAC to NC, 17-19 February 1850. See also Eiranen (2015), 88-9.

${ }^{43}$ SLS, GCSA, Folder 7, MAC to NC, 2 July 1850.

${ }^{44}$ SLS, GCSA, Folder 7, MAC to NC, 8 March 1850. 
to a cause or an idea. Nevertheless, attitudes toward conduct which broke the rules of emotional control were somewhat ambivalent. It was best if masculine passion was well-controlled (through reason) and in this manner was channeled in the right way. ${ }^{45}$ In his narration, M. A. Castrén was not too worried about emotional control but trusted to the guidance of providence as his ultimate guarantee. Hence, he implies that his inner feeling, as the workings of God, could not go wrong, but would lead him irreversibly aright as some kind of national "chosen one" - a vehicle of the world spirit.

M. A. Castrén's self-narration combined religious connotations and the romantic-genius cult, both of which intertwined with nationalist thought. The nation could acquire transcendent and religion-like meanings by connecting the individual to higher virtues and immortality. The nation and its cause thus became, in a way, sacred. Also, in the spirit of romantic ideals of authenticity and sincerity, the search for the nation's "golden age" and its heroes and geniuses gained importance. The golden age would reveal the nation's true nature and "essence"-the Finnish Kalevala being a representative case. The national heroes embodied the highest national ideals and represented the meaning of those ideals in the same way as religious prophets. Ingenuity was linked to creativity, spontaneity, and originality. The top level of intellectuals transcended mere mortals. ${ }^{46} \mathrm{M}$. A. Castrén saw emotion and impulse as positive resources of his being, which testified to his special nature and its pureness. It should be noted that he used the word for feeling or emotion (känsla) in the singular. It represented an almost mystic inner force or even his essence. The strong inner feelingthe passion-was seen as essential to creating the romantic and national genius-hero.

The emotional genius was, however, weakened and sensitive. He desperately needed the emotional safe haven the woman could offer but, at the same time, this dependence gave her the power to ruffle him. For example, a somewhat minor quarrel between the couple could push M. A. Castrén into dark thoughts. He begged his fiancée not to disturb his peace, because, when it happened, he felt "a cold, like that of death,

\footnotetext{
${ }^{45}$ Shields (2007), 97-8; Frevert (2011), 116-17.

${ }^{46}$ Anthony D. Smith, Ethno-symbolism and Nationalism: A Cultural Approach (London: Routledge, 2009), 76-9, 95-7; Kramer (2011), 4, 81-5, 92, 100; T. V. F. Brogan \& R. Falco, "Genius," in The Princeton Encyclopedia of Poetry and Poetics, 4th ed., ed. by Roland Greene \& al. (Princeton: Princeton University Press, 2012), 549-51.
} 
cutting into my blood. ${ }^{47}$ It appears that it was not necessarily a rare thing for the young Natalia Tengström to lose her temper. In explaining her side of things, she would excuse her emotional outburst with an appeal to the thoughtlessness and childishness of Little Nattu. She, too, appealed to emotionality that she could not help: it was impossible to subdue the feeling. ${ }^{48}$

A gendered double standard prevailed in the emotional dynamics of the relationship. Even though both parties emphasized, in accordance with the ideals of romantic love, that they wanted to hear and share what was in their innermost hearts, the solution to discord was taken to be that Natalia Tengström would mature to the point where she could moderate her feelings. The man wished for more tolerance and patience toward his shortcomings. ${ }^{49}$ Then, she declared:

You know I have made a major, serious decision that I will never be inconsiderate again [...] I want, with God's help, always to be your own kind good Natalia. Ooh, it is so tedious to be inconsiderate! ${ }^{50}$

The double standard found here partly challenged the basic divisions of the complementarity ideal, since, in general, the man should have filled the role of the strong and protective party. However, it was in line with the idea that the home the woman prepared was a place where the man could relax and allow himself to be vulnerable. ${ }^{51}$ The trajectory of Natalia Tengström's self-narration led from the thoughtless Little Nattu to the patient wife who could control her feelings - the stereotype of the respectable national wife. Nevertheless, Little Nattu was still very much present in the somewhat naive expressions and interjections. The process of incorporating the right kind of personal nationalism into her self-narration was ongoing.

For M. A. Castrén, the legitimation of his own flaws drew from the hardships he had endured on behalf of the national cause, and the bottom line was that he required more strength and sacrifice from his fiancée. Despite emphasizing the ideal of sincerity and openness in the relationship, he wanted his fiancée to restrict her expression of negative feelings.

\footnotetext{
${ }^{47}$ SLS, GCSA, Folder 7, MAC to NC, 28 June 1850.

${ }^{48}$ SLS, GCSA, Folder 1, NC to MAC, 30 June 1850.

${ }^{49}$ SLS, GCSA, Folder 7, MAC to NC, 7 February 1850, 8 March 1850, 2 July 1850; SLS, GCSA, Folder 1, NC to MAC, 8 March 1850, 13 March 1850.

${ }^{50}$ SLS, GCSA, Folder 1, NC to MAC, 2 July 1850.

${ }^{51}$ Siltala (1999), 72, 78-9; Jalava (2005), 190-2, 196; Tosh (2007), 54.
} 
The woman was to exercise more emotional control than the man. By accomplishing this, Natalia Tengström would fulfill the ideal of the woman who sacrificed herself-her emotions in this case-for the man and, through him, for the nation.

\section{National Science and Shared Sacrifice}

The Castréns' nationalistic goals concretized in the husband's scholarly work. Both spouses were ready to make sacrifices for its sake, but they had their own gendered roles.

In general, the idea of self-sacrifice was important to nationalist thought and is often associated with the ultimate sacrifice, that of giving one's life for one's country. The ideal of a national destiny motivated the requirement to sacrifice and strive in the service of the national community. This had religious connotations. Many nationalists considered their own nation to be that of "the chosen people" with a special mission. Religious history provided nationalists with a way of explaining the necessity for their community's sufferings: all chosen people had to go through ordeals which would then lead to happiness and prosperity - a redemption. Sacrifice and suffering ennobled the nationalistic cause and provided evidence of the agents' altruism. They could, indeed, offer a sense of a divine purpose. This ethos was also strong in the Finnish national ideals. ${ }^{52}$

In M. A. Castrén's letters, suffering, sorrow, and sacrifice were even conditions for experiencing genuine and deep positive emotions. ${ }^{53} \mathrm{He}$ anticipated that he and his fiancée would have to go through many dire afflictions, but that that was only natural, since "every serious endeavor requires some kind of sacrifice and abstinence." ${ }^{54} \mathrm{He}$ claimed that the most beautiful and inspirational moments of his life were those when he had sat by his lamp in the night, poor and reviled, working "for the true and the right." ${ }^{55}$ The scholar constructed himself as a selfless hero of a cause, where suffering and poverty elevated and ennobled his intellectual work for the nation. A hero worked because of his calling and was not corrupted by economic or other egoistic aspirations. However, his outlook

${ }^{52}$ Siltala (1999), 16, 31-2, 36, 40, 51-2; Jalava (2005), 177-8; Smith (2009), 77-9, 97-8; Kramer (2011), 81, 86-7, 95-9.

${ }^{53}$ SLS, GCSA, Folder 7, MAC to NC, 8 March 1850.

${ }^{54}$ SLS, GCSA, Folder 7, MAC to NC, 17-19 February 1850.

${ }^{55}$ SLS, GCSA, Folder 7, MAC to NC, 5 March 1850. 
regarding a destitute future does not appear very credible given the fact that it came on the threshold of the marriage of a celebrated scholar to the daughter of a well-off professor.

Nevertheless, the couple wanted to create a mutual perception that they were people who were ready for sacrifice if need be. This was a crucial part of their personal nationalisms and their self-image as a couple. M. A. Castrén declared that he would not betray his life goal even for his fiancée and her happiness. For her part, Natalia Tengström had assured him that she would rather suffer the worst with him than make him "betray the cause of science and the fatherland." ${ }^{56}$

Despite the idealizing picture of Natalia Tengström in her fiancé's letters, her interest and understanding toward his national scholarly work was negotiated in the correspondence. When he had to travel for his research, he hoped his fiancée would sacrifice her "private joy for a greater purpose, for the demands of science." $57 \mathrm{He}$ also pondered that his long reflections on his scholarly work and prospects in his letters represented "an uninteresting chapter" for her. ${ }^{58}$ Natalia Tengström assured him of her readiness for sacrifice and her interest and understanding regarding the man's work. In both cases, she was a bit hurt by his doubts. She claimed that she could never be so childish and egoistic that she would demand the man to neglect something that even she had to comprehend to be "the best and the right." someone, one was interested in everything that concerned them, "and even more so in a matter that has great weight and significance for You, and what You wrote to me was completely comprehensible, and not Samoyed language at all," she wrote, making a little joke referring to her fiancé's research subject. ${ }^{60}$ In Natalia Tengström's assurances one can read between the lines the mildly irritated addition "even if I am a woman." However, in a gendered way, she tied her personal nationalism tightly to her fiancé and to their emotional connection. In the detour of her narration, the national scholarly work was considered important for her because it was important to him.

\footnotetext{
${ }^{56}$ SLS, GCSA, Folder 7, MAC to NC, 17-19 February 1850. See also Eiranen (2015), 88.

${ }^{57}$ SLS, GCSA, Folder 7, MAC to NC, 17-19 February 1850.

${ }^{58}$ SLS, GCSA, Folder 7, MAC to NC, 27 February 1850.

${ }^{59}$ SLS, GCSA, Folder 1, NC to MAC, 24 February 1850.

${ }^{60}$ SLS, GCSA, Folder 1, NC to MAC, 1 March 1850.
} 
A greater sacrifice had to do with M. A. Castrén's academic position and the couple's economic situation. At one point he was offered a position as an adjunct professor in the Academy of Sciences in St. Petersburg, at the imperial capital, an offer he rejected. The fundamental problem was that even though the position would have been advantageous for his career, settling down in St. Petersburg was in contradiction to his national commitment to Finland. "I consider it one of my highest duties not to betray my science and my fatherland for any external profit," he claimed. Otherwise he felt he could not respect himself. The decision might lead to trouble and even poverty, but he could console himself with the consciousness that it was done on behalf of the fatherland. ${ }^{61}$ The decision was very closely linked to his self-image and, hence, to his personal nationalism.

In addition, the general opinion of the national circles was at stake. There were examples of harsh criticism toward men of letters who had moved or planned to move to Sweden or Russia. ${ }^{62}$ And the scholar also felt responsible for the younger national generation. He assumed that his "falling away" would be "morally disheartening" for them. As for his enemies, they would rejoice to see him sell himself to foreign service. ${ }^{63}$ Interestingly enough, receiving funding from the Academy of Sciences in St. Petersburg was not a problem: they had already partly funded his expeditions. ${ }^{64}$ The essential issue was the place of residence and activity. It was important to Castrén and to his contemporaries to remain within the borders of the Grand Duchy of Finland rather than move to the capital of the Empire, a place that was perceived by Finns to be foreign. In this sense, the personal nationalism involved was strikingly spatial, as it was linked to a specific geographical whole.

In his letters to Natalia Tengström, M. A. Castrén wrote about the issue at length and in detail. ${ }^{65}$ The extent of the reflections implies that the decision was not easy, and that the temptation was stronger than he was ready

${ }^{61}$ SLS, GCSA, Folder 7, MAC to NC, 5 March 1850.

${ }^{62}$ On the cases of J. J. Nordström, A. J. Sjögren and J. V. Snellman see Eiranen (2019a), $114,328$.

${ }^{63}$ SLS, GCSA, Folder 7, MAC to NC, 3 March 1850.

${ }^{64}$ Salminen (2002).

${ }^{65}$ SLS, GCSA, Folder 7, MAC to NC, 22 February 1850, 27 February 1850, 3 March 1850, 5 March 1850. 
to admit. The narrative repetition of the same themes implies that he wanted to convince not only his fiancée but also himself. In addition, the lengthy accounts can be interpreted as M. A. Castrén's attempt to make his academic future a common cause of the spouses and to commit Natalia Tengström to the decisions being made. He wanted to make it part of the personal nationalism for both of them.

Despite his noble and self-sacrificing tenets, M. A. Castrén could not deny that economic security promoted happiness. In addition, it was a matter of respect. With regard to the insecurity of his livelihood, he was irritated because he felt that he was not sufficiently valued and that his efforts on behalf of the national cause were not acknowledged-especially within his home country. His "feeling"-again in the singular-was hurt by the fact that he had to submit to promoting his own interests in trying to secure some sort of support for his work. ${ }^{66}$ The inner feeling and selfsacrifice he had sketched as the cornerstones of his personal nationalism would have, in the end, and in his mind, deserved a material reward in addition to the love of the woman.

Natalia Tengström had a firm opinion about her future husband's career prospects: she opposed accepting the position and moving to St. Petersburg. However, according to the gendered standards of the time, she could not express her opinion directly, let alone bluntly. Firstly, her strategy was to thank the man "cordially" for his decision not to accept the adjunct position. The other strategy was to appeal to other men's opinions (her father, J. V. Snellman, the students), and to refer to the criticism that those who had left the country earlier had received. If M. A. Castrén would do the same, she believed that people would say of him, too, that it was "unforgivable, for one's own benefit, to abandon one's own country." By keeping to the examples she set, she could express her own stance. If the man accepted the position, it would be very hard for her, she stated. Interestingly, Natalia Tengström wrote about the possibility of moving to St. Petersburg consistently in the singular "you"-about you having to give up Finland and you not feeling at home there. ${ }^{67}$ Usually at the time, the woman would self-evidently follow her husband and change her place of residence along with

${ }^{66}$ SLS, GCSA, Folder 7, MAC to NC, 27 February 1850, 3 March 1850, 8 March 1850.

${ }^{67}$ SLS, GCSA, Folder 1, NC to MAC, 8 March 1850. See also Eiranen (2019b), 9, 22. 
him. ${ }^{68}$ Nevertheless, Natalia Tengström, who was at this point still a fiancée and not a wife, appears to have implied by this subtle linguistic means that she would not leave Finland no matter what. Her words can even be interpreted to show that the decision to "abandon" Finland would have offended the essence of the national man she had fallen in love with. At the same time, the ideological motivation for declining to move to St. Petersburg was neatly in line with her being able to hold on to her family and life in Helsinki.

In the end, the outcome of the narration of both spouses was that honorable work for the right and noble goals would be rewarded. The last resort and guarantor was divine providence. ${ }^{69}$ Soon enough, M. A. Castrén received his "reward." He was appointed to be the first Professor of Finnish language and literature at the Imperial Alexander University in Helsinki. ${ }^{70}$ The achievement and the acknowledgement were, in a way, common to both spouses. "Castrén was, in a way, the hero of the day, and I [was] so inexpressibly happy!!” Natalia Castrén reminisced the day he was appointed. ${ }^{71}$ The professorship, and being the wife of a nationally significant man, was part of the personal nationalism of Natalia Castrén.

M. A. Castrén died in May 1852, after only one-and-a-half years of marriage. The cause was the renewal of the tuberculosis he had been inflicted with during his scholarly expeditions in Siberia. The 21-year-old widow was devastated. In the years that followed, she held tightly to her husband's memory and to the national cause he had advanced. It was a means of emotional survival.

I can still as before be happy for the happiness of others, everything big and beautiful that takes place in the world and above all in our own beloved fatherland. And I would not be worthy of being called Castrén's wife if I could not [ do this]..$^{72}$

${ }^{68}$ See e.g. Kai Häggman, Perheen vuosisata (Helsinki: SKS, 1994), 101.

${ }^{69}$ SLS, GCSA, Folder 1, NC to MAC, 3 March 1850, 5 March 1850; SLS, GCSA, Folder 1, NC to MAC, 8 March 1850.

${ }^{70}$ Salminen (2002).

${ }^{71}$ NLF, Kellgreniana, Coll. 99.3, NC to Sofi Kellgren, 13 March [1854].

${ }^{72} \mathrm{NLF}$, Kellgreniana, Coll. 99.3, NC to Sofi Kellgren, 1 January 1854. See also Eiranen (2015), 89-90. 
The national upbringing of their son was linked to this, too. She intended to raise him to love Finland and think of its best. She felt that, in this way, her life would not have been fruitless. ${ }^{73}$ In the personal nationalism that took shape in Natalia Castrén's sorrowful self-narration, her husband's death and her own suffering would not be in vain if the cause for which he had sacrificed his health would advance, also through their son.

\section{CONCLUSION}

The concept of personal nationalism takes seriously the question of what the national project actually meant to the people who were committed to it in their daily lives. The narrative approach is one method by which to tackle the issue of personal nationalism, that is, the experiences of the nation and the national. Within this framework, personal nationalism refers to how the narrating subjects incorporate nationalism in their self-narration. In the context of a marital relationship, the emotional and gendered aspects are crucial for the construction of the national experience.

The key thread throughout the Castréns' self-narrations is the central meaning given to the nation and the national in their self-construction and in their mutual relationship. In the emotional connection constructed in the correspondence, the nationalized complementary male and female ideals created a basis and prerequisite for the idealized romantic relationship.

The man was proactive in applying the national framework to their gendered selves and to the relationship. This also provided a way of expressing his expectations for the future marriage and its gendered roles. This, indeed, created pressure on the young bride. She was dedicated to the national cause in her own right, too, but in this gendered dynamic she could not express it explicitly. Her gendered strategy was to mediate her personal nationalism through men: the fiancé and her feelings for him, her father and other men in the same social circle, and their authority.

The trajectory of their personal nationalisms in the self-narrations was that self-sacrifice for the nation would (and should) be rewarded. This mirrored religious redemptive ideas. M. A. Castrén's personal

\footnotetext{
${ }^{73}$ NLF, Kellgreniana, Coll. 99.3, NC to Sofi Kellgren, 1 January 1854.
} 
nationalism was, in this sense, self-contradictory. He wanted to conceive of and represent himself as self-sacrificing, but, at the same time, he narrated himself as a passionate national genius or hero. The paradox is that in order to be a national hero, you had to sacrifice, but in order to be altruistic with respect to your sacrifice, you could not toot your own horn. This is not to say that the sacrifice was made because of the reward but was rather done with trust that it would be rewarded. Importantly, it must be remembered that the suffering at stake was not abstract but lived. The Siberian expeditions proved to have deeply affected M. A. Castrén's physical and mental state.

A key tenet in Natalia Tengström's developing personal nationalism was emotional self-sacrifice on behalf of her spouse, which was especially legitimized by his weakened physical and mental condition caused by the national sacrifice. The transition from bubbly and witty Little Nattu into a patient "national wife" took time. As a young widow, she had profoundly adopted the national ideals. In her sorrow, she found consolation and meaning for her loss and her sacrifice in the belief that it had happened on behalf of the national cause.

The Castréns lived out the gendered ideals of the time and gave them a strong national but also emotional interpretation. The emotional dynamics reversed the stereotypical assumptions about the man as the stronger and non-emotional party in a heterosexual relationship. Actually, in the Castréns' case, the woman was to exercise stronger emotional control in order to accommodate the man's feelings, and, even more so, when the man was a passionate but weakened genius. Nevertheless, this was in line with the idea of the woman preparing the home to be a safe haven for the man.

In a way, the Castréns set an example of how to realize the right kind of national selves, emotions, and relationship in their lives. Their social circle conceived of them as a perfect national match, but this entailed certain expectations. They had to fulfill the ideal of romantic love and show readiness for self-sacrifice for their country instead of favoring egoistic benefits. At this point, in the mid-nineteenth century, the example was set mostly for their peers. They showed their own social circle of the educated upper and middle class how to be national.

When analyzing people's experiences and motivations, the question of sincerity versus opportunism often arises. However, the personal and deepest motivations are often opaque even to the people themselves. As 
the Castréns' case indicates, it is not either or. Experienced and sincerely felt inner drives can very well intertwine with looking out for one's own interest. It is not wise to take research subjects' statements of their sincerity at face value, but it is also inadequate to explain the motivations of individuals, or even larger groups, based solely on consideration of opportunistic goals.

To summarize and generalize, the power and appeal of nationalism was grounded on its tight connection with profound personal meanings and motivations. These meanings and motivations affected people's sense of self and their closest, most important relationships-the very core of their being and lives.

Open Access This chapter is licensed under the terms of the Creative Commons Attribution 4.0 International License (http://creativecommons.org/licenses/ by $/ 4.0 /$ ), which permits use, sharing, adaptation, distribution and reproduction in any medium or format, as long as you give appropriate credit to the original author(s) and the source, provide a link to the Creative Commons licence and indicate if changes were made.

The images or other third party material in this chapter are included in the chapter's Creative Commons licence, unless indicated otherwise in a credit line to the material. If material is not included in the chapter's Creative Commons licence and your intended use is not permitted by statutory regulation or exceeds the permitted use, you will need to obtain permission directly from the copyright holder.

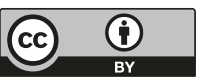

